\title{
EUROPEAN ADDED VALUE OF THE COMMON AGRICULTURAL POLICY, A NEW EFFECT OF THE REGIONAL INTEGRATION
}

\author{
Julian T. Krzyżanowski, PhD hab., Associated Professor ${ }^{1}$
}

Faculty of Economic Sciences, Warsaw University of Life Sciences - SGGW

\begin{abstract}
Integration links in the European Union are particularly strong in agriculture and in this sector joint actions have brought the most visible effect - the implementation of the common agricultural policy. The concept of European Added Value (EAV) can contribute to understanding and assessing the relevance of the CAP to the European Union. The CAP is one of the few EU policies which is chiefly implemented at the EU level and closely linked to the subsidiarity principle, according to which the EU takes on tasks which it can implement more effectively than the Member State governments and regions. EAV derived from the CAP has its own specificity. It creates new values in rural areas and agriculture, but also provides economic, social and environmental effects beyond agriculture. A couple of new values and effects are exemplified in the present paper. It shows the CAP's contribution to other areas as well as to the UN's sustainable development objectives. Further research studies on Added Value can contribute to the theory of regional economic integration.
\end{abstract}

Keywords: European Union, Common Agricultural Policy, Added Value JEL codes: A10, E00, F10, F15, F53, Q18

\section{INTRODUCTION}

The question what the common agricultural policy owes its success to, is an interesting research issue. Undoubtedly, the constant adaptation of the Common Agricultural Policy to the changing world is one of the reasons. Its evolution and policy achievements to date are illustrated well by the EC Communication of November 2017 entitled 'The Future of Food and Farming', announcing further reforms of the CAP after 2020 (European Commission, 2017a).

The EC Communication highlights the key role of the CAP in the development of an integrated single market for EU agricultural products, which is reflected in providing consumers with food of proven quality. Direct payments introduced under the CAP (the principal aid instrument for farmers) provide income support to farms, affecting their viability and competitiveness. These effects are also reinforced by the CAP market measures. Rural development support measures (Pillar II under the CAP), in turn, contribute - through targeted operations - to rural economic development, i.a. through support for investments, organisation of farmers and strengthening the food chain, development of farmers' skills and knowledge transfer, as well as through environmental/climate change combatting measures and new non-agricultural jobs.

Thanks to the efforts of the EU's agricultural and food processing sector as well as adequate trade policies and promotion strategies under the CAP, the EU is the world's largest exporter of agri-food products. At the same time, products which do not meet certain

${ }^{1}$ Corresponding author: Nowoursynowska 166, 02-787 Warsaw, Poland, Julian_Krzyzanowski@sggw.pl, +4822 5934102 
food safety standards and animal welfare criteria are not allowed to enter the EU. According to the Communication, the CAP is also planned to contribute to tackling migration issues. It will stand for agriculturerelated trainings and projects in migrants' origin and transit areas as well as assistance provided to legal refugees to enable their settlement in EU countries and integration into rural communities. As it can be perceived, the CAP supports present day challenges, not necessarily directly related to agriculture. Out of the 17 sustainable development objectives by 2030 promoted by the UN, 12 are directly or indirectly implemented through the Common Agricultural Policy (Fig. 1). Thus, this is undoubtedly a policy of the future, which for 60 years has fostered the development of agriculture and rural areas and - through care for the environment and provision of food - the entire societies in the European Union.

However, how come the CAP manages to operate on so many levels with its effects not only in the agricultural sphere? And here, the concept of European Added Value (EAV) can be applied.
The objective of this paper is presentation of the European Added Value category and its manifestations in the economic life of the Community. Especially pronounced effects of EAV are being seen in the broadly defined agricultural and rural development sphere of the EU countries. The European value shows its external effect through collective actions within the Common Agricultural Policy. Recognition of the EAV category and its different forms and areas (agricultural included) serves as an introduction to further, broader and deeper research, concerning driving forces behind the world integration processes.

\section{THEORETICAL BACKGROUND}

Generally, European Added Value means an added value (benefits) derived from actions (policies) implemented at the European level compared to the effects which would be achieved by separate policies of individual Member States within a given area (RAND Corporation, 2013).

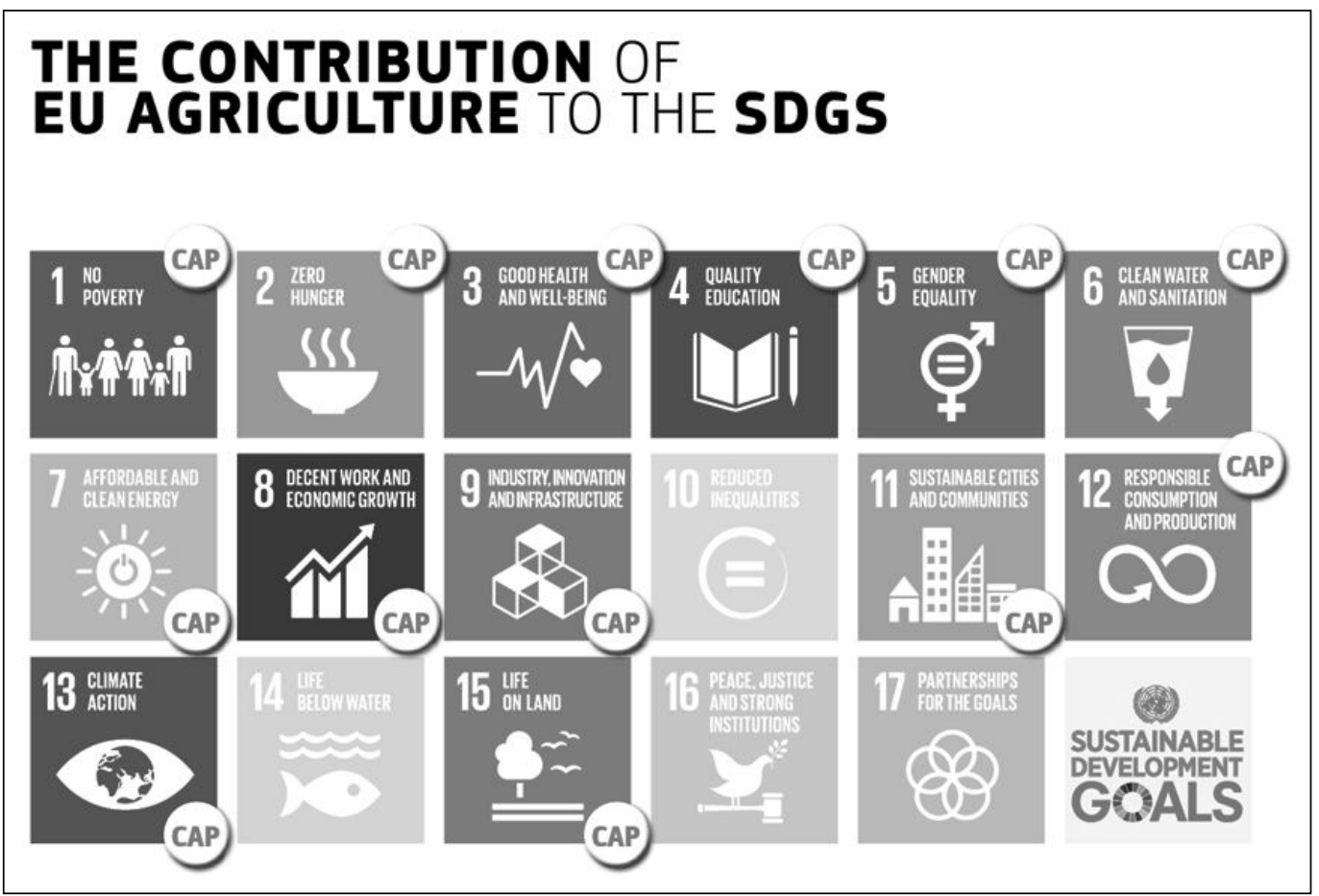

Figure 1. Sustainable development goals Source: European Commission (2017a). 
The concept of European Added Value (EAV) can contribute to understanding (and assessing) the relevance of the CAP to the European Union. The CAP is one of the few EU policies which is chiefly implemented at the EU level and closely linked to the subsidiarity principle, according to which the EU takes on tasks which it can implement more effectively than the Member State governments and regions (Ministerstwo Rolnictwa i Rozwoju Wsi, 2017).

Looking for the origins of European Added Value (EAV), it is necessary to go back to $1992 / 1993$ and the Maastricht Treaty establishing the European Union. The concept of EAV derives from three principles: subsidiarity, proportionality and additionality, the first two are enshrined in Article 5 of the Treaty (RAND Corporation, 2013) and then further construed in a specific protocol (Protocol No 30).

According to the principle of subsidiarity, in areas which do not fall within its exclusive competence, the EU starts operating only if and in so far as the objectives of any intended action cannot be sufficiently achieved by the Member States, either at the central level or at the regional and local level, and can therefore, by reason of the scale or effects of this action, be better achieved by the EU. In accordance with the principle of proportionality, the scope and form of action undertaken by the EU do not go beyond what is required in order to achieve the objectives of the Treaties.

The Protocol No 30 to the Treaty states that, for the Community action to be justified, the principles of subsidiarity and proportionality must be attained: the objectives of any intended action cannot be sufficiently achieved by the Member States within the framework of their national constitutional systems, and can therefore be better attained by action at the Community level.

The potentiality of EAV derives from respecting the above principles. However, the concept of Added Value is broader than both. Subsidiarity and proportionality are intended to give legitimacy to action under- taken by the EU in the legal sense. One aspect of how EAV is manifested comes to its economic relevance. The condition of its formation and the type of value created are important here. The creation of EAV is also not limited by the EU's borders. New value can be created, for example, in the form of development aid.

The concept of European Added Value was strongly emphasised during the discussion on the EU budget for 2014-2020. According to the European Commission, EAV can be best defined to be a value 'additional to the value created by actions of individual Member States' (European Commission, 2014).

At the same time, European Added Value was highlighted in the theory of regional economic integration (Robson, 1998), while analysing externalities. European Added Value is a value which comes from the fact that an individual action is not undertaken at the Member State level but at the EU level. The mere establishment of a common approach for dealing with a given issue can be considered an added value, since it creates a single framework for action and ensures the operation of the EU single market, which is considered as an example of EAV. The specific structure of trade in the EU Member States, where the trade in goods with other EU countries is higher than the one with third countries (Gorzelak et al., 2017) is also considered a manifestation of added value.

However, it can be concluded that EAV is not a mere added value. In fact, EAV is an manifestation of the synergy effect, i.e. cooperation at the regional level ${ }^{2}$. Currently, EAV has been increasingly identified with the synergy effect (European Commission, 2017b) .

Community-level actions form EAV because:

- Many elements are of a cross-border nature, i.e. they concern other sectors. For example, the CAP is linked to the Single Market, which in turn depends on global markets. Climate, water and air quality issues are clearly of a cross-border nature.

- Actions on common issues are more effective when undertaken at a higher level of centralisation.

${ }^{2}$ Synergy (synergy effect, gr. $\sigma v v \varepsilon \rho \gamma i \alpha$ 'cooperation') - interaction/cooperation of various factors, the effect of which is higher than the sum of individual separate operations. As a result of synergy, for example, merged companies generate a higher profit than the sum of profits of individual companies before their merger. The main reasons for synergies are: reduction of costs and increase in the sales of each company (Corning, 2003). 
- The shared budget builds solidarity. Thus, projects can be implemented in the Member States or regions, even where there is a lack of local funding there.

Just in the case of the budget it can be assumed that these funds bring more benefits than if they were spent by individual Member States. Here the theory of 'fiscal equivalence' can be applied (Olson, 1969). According to it, state-level structures should be organised in such a way that, when the state provides a public good, there should be convergent interests of beneficiaries, decision-makers and taxpayers. If this is the case, there are no cross-border (negative) external effects and public goods are provided efficiently.

Thus, it can be argued that European public goods should be provided at the EU level (ECORYS, CPB, IFO 2008; Collignon, 2011). It refers to, among others:

- border control,

- defence policy,

- internal security,

- regulations on the common market,

- trade and competition policy,

- environment, combatting climate changes, energy policy;

- R\&D and education policy.

It can even be argued that the European integration creates new European public goods which can only be provided effectively at the European level. They include, for example: lowering trade barriers, migration policy, flows of production factors. It can also be proved that managing the implementation of tasks from the EU level lets the Member States to achieve better results than their all actions at the national level and above all to reduce (save) resources. This is when EAV is created (Heinemann, 2011).

\section{MATERIALS AND METHODS}

The paper is based on the analysis of the literature in the field and the European Union documentation. The analysis starts with a clarification of the concept of European Added Value followed by tracking the process of interest into this phenomenon. Subsequently, EAV and its creation under the EU Common Agricultural Policy actions and measures was discussed. On these grounds, some general conclusions have been drawn.

\section{RESULTS AND DISCUSSION}

European Added Value implemented under the CAP has its specificity:

- It creates new values in rural areas and agriculture

- It generates economic, social and environmental effects also beyond agriculture.

Point 1. The CAP pursues the objectives specified in the Treaty of Rome, among which food security for Europe is crucial. The CAP provides affordable food to consumers, bringing household expenditure on food (and non-alcoholic beverages) in the EU down gradually to $12.3 \%$ of total expenditure in 2014 (compared to over $30 \%$ in the 1960s) (Eurostat, 2017). This is undoubtedly an added value. Similarly, the EU saves $€ 23$ billion a year compared to the case without the CAP (RAND Corporation, 2013) $)^{3}$. The common agricultural policy plays the role of a guarantor of the European agricultural model, which is a relevant social asset. Without the CAP, many European countries could quickly concentrate and intensify their agricultural production (such as the USA) and set up industrial-scale agricultural businesses with all its social and environmental effects. Apart from food security, the Common Agricultural Policy now provides EU citizens with access to a wide range of agricultural public goods (Cooper, Hart and Baldock, 2009; Institute for European Environmental Policy, 2011), such as: appropriate state of the natural environment (including water and air quality, soil functionality), vitality of rural areas, animal welfare, landscape elements and structure or biodiversity. Many of these goods are 'non-marketable' and of cross-border character (e.g.

\footnotetext{
${ }^{3}$ In the case study conducted for 21 Member States covered by the CAP, the authors of 'The European Added Value of EU Spending: Can the EU Help its Member States to Save Money?' stated that from 2007 onwards, the likely national agricultural policies (in case of no CAP) would exceed the CAP expenditure. Expenditure by the national agricultural policies could be EUR 23 billion higher than that of the CAP alone in 2010. Vide The European Added Value of EU Spending: Can the EU Help its Member States to Save Money? RAND Corporation (2013).
} 
air quality, climate, water). They make an integral part of the high standard of EU citizens' living and one of the key elements of the integrated approach to public health. The CAP facilitates effective prevention and reduction of negative effects of natural and climatic phenomena and crises related to plant and animal diseases, which occur more and more often in recent years and affect more than one EU Member State.

Point 2. The CAP is not just a sectoral policy any more. Further reforms of this policy, taking advantage of the multi-functionality of agricultural activities, have included - within the CAP - various EUrelevant areas, among others the ones related to environmental protection (e.g. combating biodiversity loss) or preventing climate changes.

In the forthcoming financial perspectives, under the Treaty objectives, the CAP will pursue the priorities set for the whole EU, as set out in the political process. For 2014-2020 they are:

- cost-effective food production;

- sustainable management of natural resources and climate-driven actions;

- ensured sustainable territorial development.

The CAP has been playing an increasing role in the introduction of a new economic model in the EU i.e. the closed-loop economy, as an alternative to the linear economic model ('we produce, use and dispose of'). The CAP also sets up a common framework for the operation of the agricultural sector in the EU (Marinello, Sapir and Terzi, 2015). The absence of the CAP would prevent the emergence of an efficient common agri-food market in the EU because the Member States would compete with one another with the level of their support for agriculture, which could also lead to increased expenditures in their national budgets for agriculture (RAND Corporation, 2013). Competition disturbances would result from differences in the level of aggregated budget support and the measures applied.

The operation of the single market is also facilitated by the quality standards of agri-food products introduced by the CAP. The absence of common food safety and quality standards would significantly impede trade within the European Union. The CAP provides (in fact irreplaceable) cross-border public goods at the EU level. The CAP also effectively counteracts the external effects of agricultural activity and protects European citizens against global threats. The creation of added value in various areas is shown in Figure 2.

\section{THE CONTRIBUTION OF EU AGRICULTURE TODAY}

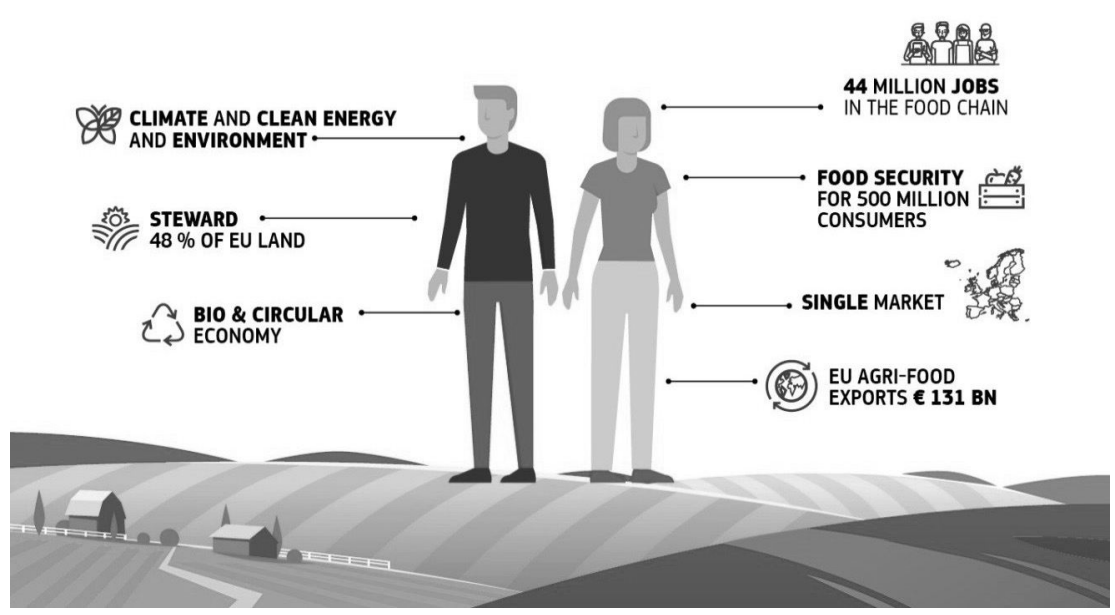

Figure 2. Contribution of the CAP funds to various spheres of activity Source: European Commission (2017a). 


\section{CONCLUSIONS}

The CAP is active on many economic and social levels also beyond agriculture. It can be said that its effective operation is made possible by the creation of European Added Value (EAV). According to many researchers, EAV is created through actions undertaken in the field of regional integration. It is also an effect of synergy. EAV is an interesting concept in cognitive terms. It is created not only in agriculture, but also wherever there is any joint action at the Community level. Taking the European Union as a model, it can be analysed whether such added value is created in other emerging economic groups being at various stages of their integration development. If the answer was positive, it would confirm the hypothesis that the creation of added value is a universal process, directly resulting from integrative operations. Going further, it could be argued that the effect of added value is the third effect (next to the two known from the theory of economic integration: trade creation and trade diversion effects), resulting from the creation of integration links.

\section{REFERENCES}

1. Collignon, S. (2011). The Governance of European Public Goods. In: Tarschys, D. (ed.) The EU Budget. What should go in? What should go out? Swedish Institute for European Policy Studies, Stockholm, pp. 42-57.

2. Cooper, T., Hart, K, Baldock, D. (2009). Provision of Public Goods through Agriculture in the European Union. Institute for European Environmental Policy, London.

3. Corning, P.A. (2003). Nature's Magic: Synergy in Evolution and the Fate of Humankind. Cambridge University Press, New York.

4. Council of the European Communities (1992). Treaty on European Union. Retrieved from: https:/europa.eu/ europeanunion/sites/europaeu/files/docs/body/treaty_ on_european_union_en [Accessed 10.05.2018].

5. ECORYS, CPB, IFO (2008). A Study on EU Spending. Final Report. Rotterdam.

6. European Commission (2001). Ex ante Evaluation. A Practical Guide for Preparing Proposals for Expenditure Programmes.

7. European Commission (2014). Funding under the 3rd health programme 2014-2020. The European added value. Retrieved from: http://ec.europa.eu/chafea/documents/health/hp-factsheets/added-value/factsheets-hpav_en.pdf.

8. European Commission (2017a). Communication from the Commission to the European Parliament, the Council, the European Economic and Social Committee and the Committee of the Regions. The Future of Food and Farming. COM(2017) 713 final of 29.11.2017.

9. European Commission (2017b). Assessment of the Union Added Value and the economic impact of the EU Framework Programmes (FP7, Horizon 2020). Brussels.

10. Eurostat (2016). Household expenditure by purpose in the EU, 2015. Retrieved from: http://ec.europa.eu/eurostat/news/themes-in-the-spotlight/household-expenditure [Accessed 08.05.2018].

11. Gorzelak, A., Herda-Kopańska, J., Kulawik, J., Soliwoda, M., Wieliczko, B. (2017). Kontrowersje wokół europejskiej wartości dodanej tworzonej przez WPR [Controversies over the European Value Added created by CAP]. Zagadnienia Ekonomiki Rolnej, 1, pp. 4-5.

12. Heinemann, F. (2011). European Added Value for the EU Budget. In: Tarschys, D. (ed.) The EU Budget. What should go in? What should go out? Swedish Institute for European Policy Studies, Stockholm, pp. 58-73.

13. Institute for European Environmental Policy (2011). What tools for the European Agricultural Policy to encourage the provision of public goods? London.

14. Mariniello, M., Sapir, A., Terzi, A. (2015). The long road towards the European Single Market. Bruegel Working Paper.

15. Ministerstwo Rolnictwa i Rozwoju Wsi (2017). Europejska wartość dodana wspólnej polityki rolnej (WPR) w kontekście unijnego budżetu [European Added Value of Common Agricultural Policy in the context of the EU budget]. Warszawa.

16. Olson, M. (1969). The Principle of Fiscal Equivalence: The Division of Responsibilities among Different Levels of Government. American Economic Review, 59 (2), pp. 479-487.

17. Protocol No 30 on the application of the principles of subsidiarity and proportionality of the Treaty establishing the European Community. OJ C 325 of 24.12.2002.

18. RAND Corporation (2013). The European Added Value of EU Spending: Can the EU Help its Member States to Save Money? Exploratory Study. Bertelsmann Stiftung, Gütersloh.

19. Robson, P. (1998). The Economics of International Integration. Routledge, London. 